\title{
Carbon and nitrogen content of copepod faecal pellets: effect of food concentration and feeding behavior
}

\author{
Carmen E. Morales* \\ Department of Oceanography, Dalhousie University, Halifax, Nova Scotia B3H 4J1, Canada
}

\begin{abstract}
The chemical composition was analyzed of faecal pellets produced by copepods from Bedford Basin (Nova Scotia, Canada), mainly Pseudocalanus spp. and Temora longicornis, fed different concentrations of the diatom Thalassiosira weissflogii. The feeding response of copepods to day-to-day changes in food concentration involved adjustments of ingestion rate in $<24 \mathrm{~h}$; diel differences in ingestion rate were found in copepods acclimated to high food concentration but not in those acclimated to low food concentration. Carbon and nitrogen content of faecal pellets (percentage of dry weight) was independent of food concentration, acclimation period to a given food concentration, and ingestion rates. Mean pellet composition was $25 \% \mathrm{C}$ and $3 \% \mathrm{~N}$; a higher C:N ratio in faecal pellets (7 to 9) as compared with that of the food (5.5) suggested that $N$ was assimilated more efficiently than $C$. These results suggest that single values of the chemical composition of pellets might be used to estimate vertical flux of carbon and nitrogen via zooplankton faecal pellets. However, a comparison with literature data suggests that differences in carbon and nitrogen content of copepod faecal pellets might result from differences in food quality.
\end{abstract}

\section{INTRODUCTION}

Estimations of the trophic transfer and removal of carbon and nitrogen from surface layers of the water column via zooplankton faecal pellets depend on a knowledge of the chemical composition of these pellets. Carbon and nitrogen content of faecal pellets has been directly measured (Johannes \& Satomi 1966, Kraneis \& Martens 1975, Honjo \& Roman 1978, Turner 1979, Bruland \& Silver 1981, Madin 1982, Tanoue et al. 1982, Small et al. 1983, Abou Debs 1984), or estimated (Knauer et al. 1979, Paffenhöfer \& Knowles 1979, Hofmann et al. 1981, Urrere \& Knauer 1981, Gowing \& Silver 1985). In all these cases, it has been implicitly assumed that the faecal pellet composition is not influenced by type or concentration of food. This assumption seems critical to the evaluation of faecal fluxes in terms of carbon and nitrogen and its validation requires an understanding of the adaptations of zooplankton to a variable food environment and the relationship of these adaptations to faecal pellet production.

\footnotetext{
- Present address: Edificio Montecarlo (San Martin 570) Block D, depto. 16, Vina del Mar, Chile
}

Ingestion and assimilation have a direct effect on the faecal production of zooplankton, in terms of composition and/or production rates, and therefore influence the downward flux of carbon and nitrogen. However, the overall effects of both factors on the composition and the production rate of faecal material are not sufficiently known. Landry et al. (1984) predicted that changes in the assimilation efficiency of Calanus pacificus, as affected by changes in food concentration, might result in a difference of up to 3.5 times in the nitrogen content of faecal material. Checkley (1980) concluded that Paracalanus parvus utilizes nitrogen more efficiently than carbon, and Checkley \& Enzeroth (1985) postulated a positive relationship between the $\mathrm{C}: \mathrm{N}$ ratio in faeces and that in the food, applicable to tropical and subtropical copepod populations. All these results suggest that important changes in the composition of faecal material might occur in response to different food conditions, which is in contrast with the assumption of independence between these 2 variables.

In an attempt to determine the factors that influence the production of zooplankton faecal pellets, the response of copepod assemblages from Bedford Basin 
(Nova Scotia, Canada) to food concentrations, and to short-term variations in these concentrations, was investigated under laboratory conditions. It was assumed that these copepods experience significant food variations on the scale of days and, therefore, they are continuously acclimating to these variations (Mayzaud \& Mayzaud 1985). The hypothesis was tested that significant changes would occur in the composition of copepod faecal pellets (as carbon and/or nitrogen content per unit dry weight) in response to different food concentrations and acclimation periods to a given concentration, and the resultant ingestion rates.

\section{MATERIALS AND METHODS}

Two laboratory experiments were performed in which groups of copepods were acclimated to either a low or a high food concentration of the diatom Thalassiosira weissflogii for a number of days after which some or all the groups were briefly exposed to a higher concentration. The food acclimation period assumed that the acclimation time of Bedford Basin copepods was $>24 \mathrm{~h}$ and $<6 \mathrm{~d}$ (Mayzaud \& Poulet 1978); therefore, exposure to a change in food concentration for the first $24 \mathrm{~h}$ represented the condition of no acclimation in this case. In Experiment I, the food concentrations used were within the range (ca 40 to $600 \mu \mathrm{C}^{-1}$ ) observed in Bedford Basin (Poulet 1976). Copepods at low food concentration were acclimated to 700 cells $\mathrm{ml}^{-1}$ (ca $70 \mu \mathrm{g} \mathrm{C} \mathrm{l}^{-1}$ ) for $6 \mathrm{~d}$, after which they were exposed to 5000 cells $\mathrm{ml}^{-1}$ for $2 \mathrm{~d}$. Faecal samples taken on Days 5 and 6 represented the condition of acclimation to low food concentration and, on Day 7, no acclimation to high food concentration. Other copepods were acclimated to a high concentration (4500 cells $\mathrm{ml}^{-1}$ ) for the whole period (8 d); faecal samples collected on Days 6 and 7 represented acclimation to high food concentration. Experiment I was performed in November 1985 and the copepod assemblage used consisted predominantly of later stages of Temora longicornis and Pseudocalanus spp.

In Experiment II, extreme food concentrations were used to increase the range of concentrations over which the faecal pellet composition might be affected.

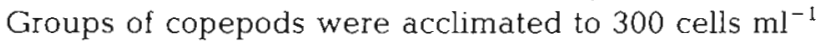
(ca $30 \mu \mathrm{g} \mathrm{C} \mathrm{l}^{-1}$ ) for $3 \mathrm{~d}$, after which they were starved for $1 \mathrm{~d}$ and then given a high concentration $(3500$ cells $\mathrm{ml}^{-1}$ ) for $1 \mathrm{~d}$. Faecal pellets from Day 3 represented acclimation to low food concentration and those from Day 5, no acclimation to high food concentration with previous starvation. At the same time, other copepods were acclimated to 3000 cells $\mathrm{ml}^{-1}$ for $4 \mathrm{~d}$, after which they were given 20000 cells $\mathrm{ml}^{-1}$ (ca $2 \mathrm{mg} \mathrm{C} \mathrm{l}^{-1}$ ) for $1 \mathrm{~d}$. In this case, faecal pellets from Day 3 represented acclimation to high food concentration and those from Day 5, no acclimation to a very high food concentration. Experiment II was performed in January 1986 and later stages of Pseudocalanus spp. were predominant in the assemblage used.

Copepods were collected at a central station in Bedford Basin during the morning with an open net towed at $15 \mathrm{~m}$ depth for 5 to $10 \mathrm{~min}$. These copepods were transferred to a $10^{\circ} \mathrm{C}$ room and set in a $12 \mathrm{~h}$ light-dark cycle with diffuse and dim light (ca $1 \mu \mathrm{E} \mathrm{m}^{-2} \mathrm{~s}^{-1}$ ). During the first $24 \mathrm{~h}$ after capture, copepods were allowed to acclimate to the experimental temperature and a low quantity $\left(<100 \mu \mathrm{g} \mathrm{C}^{-1}\right.$ ) of Thalassiosira weissflogii was provided.

Experimental containers consisted of an acrylic, rectangular column with a square base (20 1), a polyethylene funnel inserted in this base, and an acrylic cylinder (10 l) with a $233 \mu \mathrm{m}$ mesh glued to its bottom and resting on top of the funnel (Morales 1986). Copepods were placed in the cylinders and the faeces produced were deposited in the funnel. Mixing devices were not used so that faecal pellets would settle directly to the bottom of the container. The water in the containers was changed daily with fresh, $10^{\circ} \mathrm{C}$ filtered $(<1 \mu \mathrm{m})$ seawater. Copepod abundance per cylinder (300 to 500) was within the range of values for adult copepods reported in Bedford Basin (Poulet 1978).

Thalassiosira weissflogij was grown in batch cultures with h/2 medium (Guillard 1975) and maintained under a light-dark cycle at 13 to $15^{\circ} \mathrm{C}$. Seriallyinoculated cultures were harvested daily to maintain a culture of nearly constant age ( 4 to $5 \mathrm{~d}$ ). The carbon and nitrogen composition of the algae was determined during some periods over which faeces were collected. Algal samples $(10 \mathrm{ml})$ were filtered onto pre-combusted $\left(450^{\circ} \mathrm{C}\right.$ for 3 h) glass fibre filters (Gelman ${ }^{\circledR} \mathrm{AE}$, $13 \mathrm{~mm}$ ), dried and then analyzed for carbon and nitrogen content (Carlo Erba ${ }^{\circledR} \mathrm{CHN}$ analyzer, model 1106).

A given food concentration was provided to the copepods twice a day, at the beginning of the light and the dark period. The experimental changes in food concentration were made at the beginning of the light period. Complementary observations were made in the absence of copepods to determine changes in algal concentration, in spatial and temporal distribution in the cylinders, and changes in the chemical composition of the algae, over one (ca $12 \mathrm{~h}$ ) or 2 consecutive experimental intervals.

Ingestion (I), in number of cells copepod ${ }^{-1} \mathrm{~h}^{-1}$, was calculated from the equation:

$$
\mathrm{I}=[\mathrm{V} /(\mathrm{M} \times \mathrm{T})] \times(\mathrm{CI}-\mathrm{CF})
$$

where $\mathrm{V}=$ water volume in the cylinders $(9.5 \mathrm{l})$; $M=$ number of copepods per cylinder (300 to 500); 
$\mathrm{T}=$ feeding interval $(\mathrm{ca} 10 \mathrm{~h}) ; \mathrm{CI}$ and $\mathrm{CF}=$ initial and final algal concentrations. Estimates of algal concentration were made with a Coulter Counter ${ }^{\circledR}$ (model ZB, $100 \mu \mathrm{m}$ aperture tube). Ingestion rates were obtained for light and dark feeding intervals, and also an estimate of daily ingestion was calculated by multiplying the corresponding day and night rates by 12 and adding the resultant values.

Faeces were collected daily in the morning by draining all the water from the containers, after removing the cylinders with the copepods, and simultaneously sieving the flow with a $35 \mu \mathrm{m}$ mesh to remove algal cells. After a second sieving the material collected was examined microscopically and faecal pellets were separated from other particles, mostly copepod eggs. Faecal samples were kept at $<3^{\circ} \mathrm{C}$ until subsequent processing within $15 \mathrm{~h}$. These samples were then briefly rinsed in distilled water to remove salts and immediately filtered onto pre-combusted, preweighed glass fibre filters (Gelman ${ }^{\circledR} \mathrm{AE}, 13 \mathrm{~mm}$ ). The filters with the samples were oven-dried $\left(60^{\circ} \mathrm{C}\right)$ for 24 to $36 \mathrm{~h}$ and then stored in a desiccator. The faecal samples were then weighed and corrected for change in weight (ca $10 \mu \mathrm{g}$ ) of blank filters; dry sample weights were in the range of 100 to $400 \mu \mathrm{g}$ dry weight. Analysis for carbon and nitrogen content in faecal pellets was carried out as for algal samples (Morales 1986). It was assumed here that microbial activity did not affect faecal pellet composition during the period required to obtain a sample, including time for defecation $\left(24 \mathrm{~h}\right.$ at $\left.10^{\circ} \mathrm{C}\right)$ and the subsequent processing of the material $\left(15 \mathrm{~h}\right.$ at $\left.<3^{\circ} \mathrm{C}\right)$. At these temperatures, microbial activity should not significantly modify the carbon and nitrogen content of copepod faecal pellets covered with a peritrophic membrane (Honjo \& Roman 1978, Turner 1979, Jacobsen \& Azam 1984).

\section{RESULTS}

\section{Food conditions}

Changes in food conditions over one or 2 experimental intervals, monitored in the absence of copepods, showed negligible variations. Growth of Thalassiosira weissflogii was less than $6 \times 10^{-2}$ divisions per experimental interval, and algal spatial distribution in the cylinders, comparing the algal concentration in the surface and the bottom of the cylinders, was not significantly different (t-test for paired comparisons, $p>0.05$ ). Algal carbon and nitrogen content was similar within and between experiments (Table 1); an estimate of $86.5 \mathrm{pg} \mathrm{C}$ and $16.4 \mathrm{pg} \mathrm{N}$ per cell was obtained. Single cells were ca $15 \mu \mathrm{m}$ in length and $1900 \mu \mathrm{m}^{3}$ in volume. Initial food concentrations in both experiments remained approximately constant during the acclimation period at a given food concentration, the coefficient of variation usually being $<10 \%$.

\section{Feeding behavior}

Diel differences in ingestion rate between light and dark intervals, including periods of 3 to 8 consecutive $d$, at low food concentrations were either not significantly different (Fig. 1, p >0.05) or only slightly different (Fig. 2, $0.05>p>0.01$ ) (t-test for paired comparisons). At high food concentrations, ingestion rates in the light were significantly lower than in the dark in both experiments $(p<0.001)$. The change from low to high food concentration resulted in similar feeding behavior to that observed in copepods acclimated to high food concentrations, except when copepods were previously starved (Experiment II), in which case ingestion rates in the light and the dark were apparently not different. Ingestion rates in the light, including periods of 2 to 8 consecutive d, were slightly higher at high food concentrations than at low concentration $(0.05>p>0.01$, Wilcoxon 2-sample test) in both experiments. The comparison excluded data from Day 5 in Experiment II when copepods were exposed to extreme food concentrations for $1 \mathrm{~d}$ only.

In Experiment I (Fig. 1), the change to a higher food concentration for copepods acclimated to a low food concentration resulted in a similar diel trend and rate of ingestion as for copepods acclimated to a high food concentration, at least for the first day. This indicated that the copepods adjusted their ingestion rates within $24 \mathrm{~h}$ in response to changes in food concentration. In Experiment II (Fig. 2), copepods previously starved and then exposed to a high concentration, showed similar ingestion rates as those acclimated to high food concentration. However, they responded immediately to

Table 1. Thalassiosira weissflogii. Chemical composition of algal culture and its change during 2 experimental intervals (20 h). Flask $11: 5 \mathrm{~d}$ old; Flasks 2 and $3: 4 \mathrm{~d}$ old. $10^{\circ} \mathrm{C} ; 1000$ to $2200 \mathrm{~h}$ with dim light

\begin{tabular}{|ccccc|}
\hline \multirow{2}{*}{ Flask } & \multirow{2}{*}{ Time } & \multicolumn{3}{c|}{ Algal elemental composition } \\
& & Carbon & Nitrogen & C:N \\
& $(\mathrm{h})$ & $\left(\mu \mathrm{C} \mathrm{C}^{-1}\right)$ & $\left(\mu \mathrm{N} \mathrm{N}^{-1}\right)$ & \\
\hline \multirow{2}{*}{1} & - & 26.1 & 4.6 & 5.7 \\
& & 26.1 & 4.5 & 5.8 \\
2 & 2300 & 20.0 & 3.9 & 5.2 \\
& 1200 & 19.6 & 3.7 & 5.3 \\
3 & 1500 & 23.9 & 4.6 & 5.2 \\
& 2100 & 24.7 & 4.6 & 5.4 \\
& 1000 & 23.7 & 4.5 & 5.3 \\
\hline
\end{tabular}


the change and the ingestion rate was as high in the light as in the dark. Also in Experiment II, the change to a very high food concentration in copepods acclimated to a high food concentration resulted in a minimal ingestion rate in the light and a doubling of the rate in the dark with respect to the previous rate in the dark. Again, this indicated that the time required for adjustments of ingestion rate in response to variations in food concentration was less than $24 \mathrm{~h}$.

Daily ingestion rates were calculated from the above data to obtain an approximate value of the daily ration under different food conditions (Table 2), given that faecal pellets were collected only once a day. The estimate for the copepods exposed to a very high food concentration, which is similar to that from the same copepods acclimated to high food concentration, suggests that the occurrence of a saturation response is related to diel differences in ingcstion.

\section{Faecal pellet composition}

In Experiment I, the composition of the faecal pellets was remarkably similar among the different food conditions (acclimation to low, acclimation to high, and no

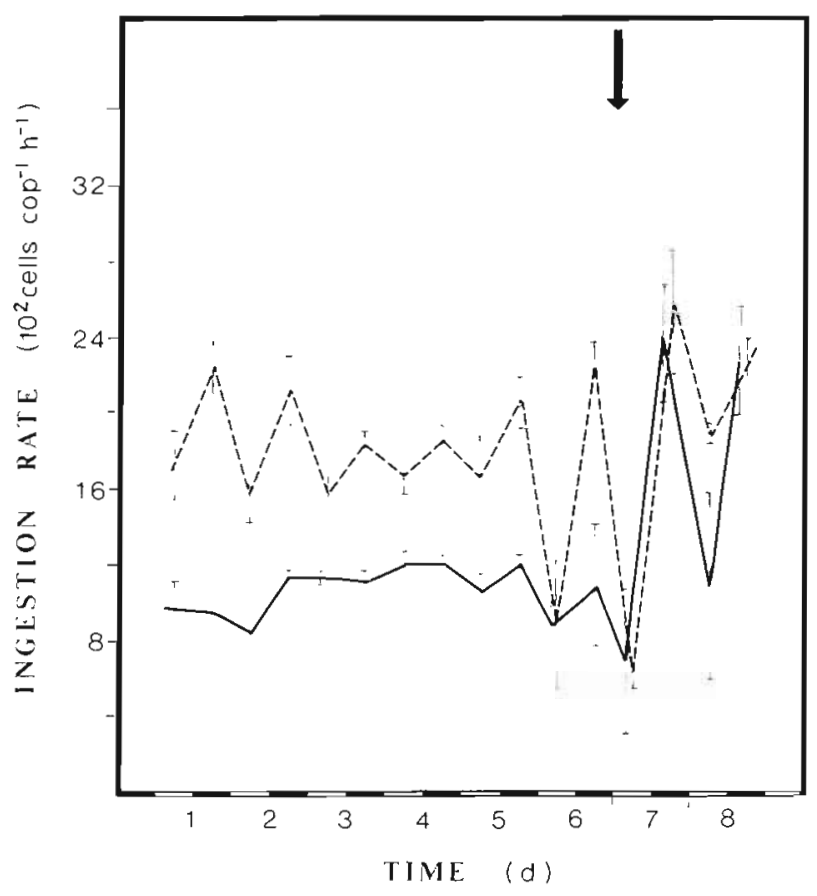

Fig. 1. Experiment I: ingestion rates by copepods from Bedford Basin (Nova Scotia, Canada), fed Thalassiosira weissflogii under light and dark conditions, for each experimental day. Mean and 1 standard deviation of 3 replicate measurements. Solid line: acclimation to low food concentration, until the change to a high concentration (arrow). Broken line: acclimation to high food concentration over the $8 \mathrm{~d}$ period acclimation to high food concentration) and the resultant ingestion rates, both in terms of carbon $(261 \pm 17 \mu \mathrm{g})$ and nitrogen $(33 \pm 3 \mu \mathrm{g})$ per unit $(\mathrm{mg})$ dry weight (Table 2). In Experiment II, the mean composition of all the samples together was not different from that of Experiment I, both for carbon $(234 \pm 28 \mu \mathrm{g})$ and nitrogen $(29 \pm 5 \mu \mathrm{g})$ per unit $(\mathrm{mg})$ dry weight. The variation was higher in this experiment but within the range of analytical error ( $\mathrm{CV}=10$ to $15 \%)$.

The faecal composition remained relatively constant within the range of food concentration and the acclimation periods used, and the resultant ingestion rates (Table 2). A statistical comparison of the faecal pellet data for the 3 conditions: (a) acclimation to low, (b) acclimation to high, and (c) no acclimation to high food concentration, showed no significant differences $(95 \%$ confidence interval).

$\mathrm{C}: \mathrm{N}$ ratios by weight in the faecal pellets ranged from 7 to 9 and were higher than those in the algae (5.5), indicating that the copepods assimilated nitrogen

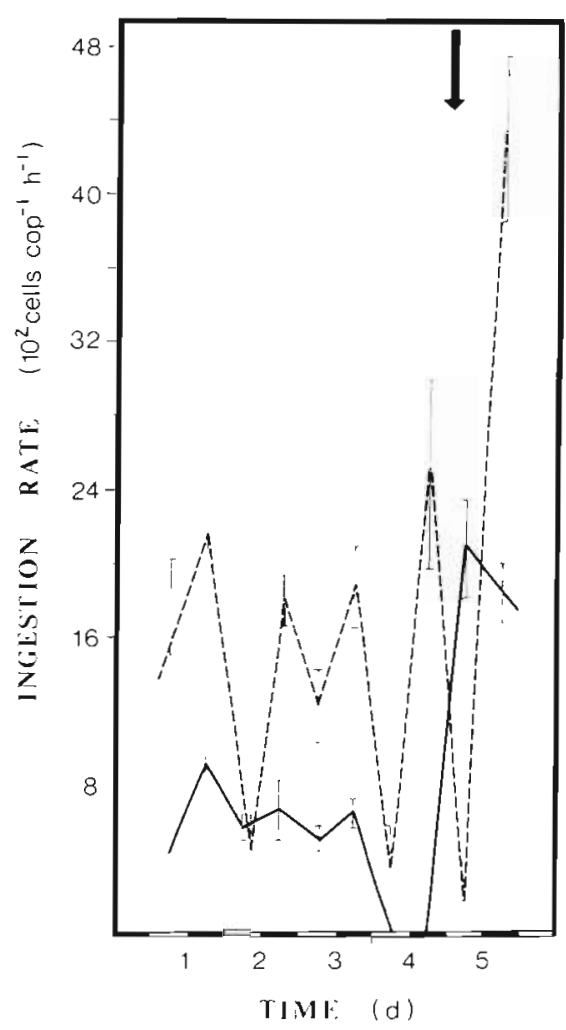

Fig. 2. Experiment II: ingestion rates by copepods from Bedford Basin (Nova Scotia, Canada), fed Thalassiosira weissflogii under light and dark conditions, for each experimental day. Mean and 1 standard deviation of 3 replicate measurements. Solid line: acclimation to low food concentration until starvation (Day 4) and subsequent exposure to a high concentration (arrow). Broken line: acclimation to high food concentration until the change to very high concentration (arrow) 
Table 2. Copepods from Bedford Basin (Nova Scotia, Canada) fed Thalassiosira weissflogii. Summary of results of Experiments I and II: food concentration, copepod ingestion rates, and chemical composition of faecal pellets. Acclimation period as specified in the text ( 1 to $6 \mathrm{~d}$ ). Mean and 1 standard deviation of replicate cylinders for only the days during which faeces were sampled. L: low, H: high, $+\mathrm{H}$ : very high food concentration; ' copepods previously starved; $n$ : number of observations; C/DW and N/DW: $\mu \mathrm{g}$ carbon and nitrogen per mg dry weight of faecal material

\begin{tabular}{|c|c|c|c|c|c|c|c|c|c|c|c|c|c|}
\hline \multirow[t]{3}{*}{ Exp. } & \multirow{3}{*}{ Food condition } & \multirow{2}{*}{\multicolumn{3}{|c|}{$\begin{array}{l}\text { Food concentration } \\
\text { (cells } \mathrm{ml}^{-1} \text { ) }\end{array}$}} & \multirow{2}{*}{\multicolumn{3}{|c|}{$\begin{array}{l}\text { Copepod ingestion } \\
\left.\text { (cells cop } \mathrm{d}^{-1} \mathrm{~d}^{-1}\right)\end{array}$}} & \multicolumn{6}{|c|}{ Faecal pellets } \\
\hline & & & & & & & & & \multicolumn{2}{|c|}{ C/DW } & \multicolumn{2}{|c|}{ N/DW } & \multirow[t]{2}{*}{$C: N$} \\
\hline & & $\mathrm{n}$ & $\overline{\mathrm{x}}$ & $\mathrm{SD}$ & $\mathrm{n}$ & $\overline{\mathrm{x}}$ & $\mathrm{SD}$ & $\mathrm{n}$ & $\overline{\mathrm{x}}$ & $\mathrm{SD}$ & $\overrightarrow{\mathrm{x}}$ & $\mathrm{SD}$ & \\
\hline II & Acclimation L & 6 & 258 & 25 & 3 & 13996 & 1908 & $3^{d}$ & 234 & 9 & 27 & 4 & 8.7 \\
\hline I & Acclimation L & 12 & 745 & 74 & 6 & 25106 & 2930 & 6 & 261 & 23 & 31 & 2 & 8.4 \\
\hline II & Acclimation $\mathrm{H}$ & 6 & 2788 & 80 & 3 & 37132 & 2880 & 3 & 234 & 8 & 32 & 2 & 7.3 \\
\hline I & Acclimation $\mathrm{H}$ & 12 & 4851 & 392 & 6 & 37604 & 4532 & 6 & 263 & 13 & 35 & 2 & 7.5 \\
\hline II & No acclimation $\mathrm{H}^{*}$ & 6 & 3557 & 483 & 3 & 47064 & 5773 & 3 & 266 & 32 & 34 & 5 & 7.8 \\
\hline I & No acclimation $\mathrm{H}$ & 6 & 5216 & 203 & 3 & 36700 & 3264 & 3 & 255 & 13 & 32 & 2 & 8.0 \\
\hline II & No acclimation $+\mathrm{H}$ & 6 & 19743 & 597 & 3 & 53656 & 3733 & 3 & 205 & 12 & 24 & 2 & 8.5 \\
\hline
\end{tabular}

more efficiently than carbon. However, the extent of this difference was not related to food conditions nor to the ingestion rates resultant from these conditions.

\section{DISCUSSION}

Carbon and nitrogen composition of faecal pellets produced by Bedford Basin copepod assemblages (mainly Temora longicornis and Pseudocalanus spp.) was found to be independent of food concentration, acclimation period to a given food concentration, and resultant ingestion rates. This statement may be of limited generality in a number of ways. First, ingestion rate at high food concentrations showed diel differences, the rates in the light being similar to those of copepods at low food concentrations. Since faeces were collected only once a day, differences in faecal composition might have been obscured; faeces production begins within minutes up to a few hours after feeding (Kiørboe et al. 1982). However, copepods previously starved and then exposed to a high food concentration (Experiment II) showed high ingestion rates both during the light and the dark periods, and the composition of faeces was not different from that of other conditions. In addition, copepods exposed to a very high food concentration (Experiment II) showed no ingestion in the light period (2 out of 3 replicates) so that faecal material analyzed represented that produced during the dark period only when ingestion was very high. In this case also, faecal composition was not different from that under the other conditions. These observations support the independence of faecal pellet composition from copepod ingestion rates. Complementarily, the observed differences in diel patterns of ingestion between copepods at low and high food concentrations support the influence of food concentration in determining these patterns (Dagg 1985).

The present experiments were carried out with copepod assemblages collected during fall and winter from surface waters. It was assumed that these copepods were not in a state of diapause and therefore were able to adjust their ingestion rates to short-term variations in food concentration. Daily ingestion rates at the different concentrations ( 1 to $5 \mu \mathrm{g} \mathrm{C} \mathrm{copepod}{ }^{-1}$ $\mathrm{h}^{-1}$ ) were within the range for neritic copepods reported in the literature. However, the rates at low food concentrations were higher than those reported for Temora longicornis and Pseudocalanus spp. in Bedford Basin (Poulet 1974, 1976, Mayzaud \& Poulet 1978) and in other areas (Gamble 1978, Koeller et al. 1979, $\mathrm{O}^{\prime}$ Connors et al. 1980). This difference might be attributed to the duration of the experimental intervals in this study (9 to $12 \mathrm{~h}$ ) relative to that of other studies (approximately $20 \mathrm{~h}$ ). In the present study, renewal of the initial food concentration after 10 to $12 \mathrm{~h}$ was intended to minimize the reduction in ingestion rates. The fact that copepods exposed to low food concentrations continued to feed at the same rate in both the light and the dark periods contributed to the higher ingestion rates obtained here. Additional factors affecting the ingestion estimates might have been container size, abundance of copepods per container, temperature, light intensity, acclimation period, and the equation used to calculate ingestion (Conover \& Huntley 1980, Roman \& Rublee 1980, McClatchie \& Lewis 1986, Stearns 1986).

A second potential limitation is the use of dry weight to compare the faecal composition, although it is usually used in evaluating vertical fluxes of particulate matter. This unit may hide differences in size and/or density (specific gravity) of faeces produced under 
different food conditions; a weight unit might contain different numbers of faecal pellets, a measure also used to express faecal fluxes (Angel 1984). Faeces produced at high food concentration can be larger than those produced at low concentration (Gaudy 1974); however, coprophagy might have influenced this observation. From observations parallel to the present study (Morales 1986), faecal pellet size was not related to food concentration although variability existed within samples (length: $310 \pm 78 \mu \mathrm{m}$; width: $44 \pm 15 \mu \mathrm{m}$ ). Differences in faecal pellet density with food concentration are only speculative (Turner 1977). On the other hand, indications of changes in the size and density of faecal pellets have been reported in relation to different food types (Marshall \& Orr 1955, Bienfang 1980).

The present results do not support the superfluous feeding hypothesis (Beklemishev 1962), which suggests that, at phytoplankton concentrations of approximately $400 \mu \mathrm{g} \mathrm{C} 1^{-1}$, the nutritional value of faecal pellets should be similar to that of the phytoplankton consumed because of inefficiencies in zooplankton digestion and/or assimilation. Also, these results do not support the prediction of a lower nutritional value for faecal pellets produced by copepods acclimated to low food concentrations and then suddenly exposed to a high food concentration, compared to that of faeces produced by copepods acclimated to a high food concentration as suggested by Landry et al. (1984) for Calanus pacificus. This may be due to species differences in the extent of the response to food variations, some species being more susceptible to food limitation than others. Recent results obtained by Frost (1985) and Ohman (1985) indicated that Pseudocalanus spp. was not food limited whereas $C$. pacificus in the same environment showed a greater dependence on variations in the food resource. The present results indicated that Pseudocalanus and Temora assemblages in Bedford Basin adapt to changes in food concentration by rapidly adjusting their ingestion rates. Although no direct measurements of assimilation efficiency were made in this study, the constancy in the chemical composition of faecal pellets produced under the different conditions suggests that potential changes in assimilation due to changes in food concentration might be only reflected in faecal production rates and/ or density (specific gravity) of faecal pellets. Of these 2, only changes in faecal density (compactness of the

Table 3. Copepod faecal pellets: carbon and nitrogen contents as reported in the literature, including Johannes \& Satomi (1966), used in the estimations of $\mathrm{C}$ and $\mathrm{N}$ fluxes via zooplankton faeces

\begin{tabular}{|c|c|c|c|c|c|}
\hline \multirow[t]{2}{*}{ Faecal producer } & \multirow[t]{2}{*}{ Food conditions } & \multicolumn{3}{|c|}{ Faecal composition } & \multirow[t]{2}{*}{ Source } \\
\hline & & Carbon & Nitrogen & $C: N$ & \\
\hline Palaemonetes pugio & Nitzchia closterium (ad libitum) & $\begin{array}{l}20 \\
\text { (percentag }\end{array}$ & $\begin{array}{c}4.5 \\
\text { of } D W\end{array}$ & 4.5 & Johannes \& Satomi (1966) \\
\hline Acartia clausi & $\begin{array}{l}\text { Coccolithophores }(200000 \\
\left.\text { cells } 1^{-1}\right) \\
\text { Natural food }\left(200000 \text { cells } I^{-1}\right)\end{array}$ & $\begin{array}{l}133 \\
96-187 \\
\text { (ng pellet) }\end{array}$ & $\begin{array}{l}13-28 \\
15-38\end{array}$ & & Honjo \& Roman (1978) \\
\hline $\begin{array}{l}\text { Undinula vulgaris } \\
\text { and small copepods }\end{array}$ & $\begin{array}{l}\text { Natural food }\left(30-40 \mu \mathrm{g} \mathrm{C}^{-1}\right. \\
\left.4-6 \mu \mathrm{g} \mathrm{N} \mathrm{^{-1 }}\right)\end{array}$ & & & $15-16$ & Gerber \& Gerber (1979) \\
\hline $\begin{array}{l}\text { Eucalanus pileatus } \\
\text { (adults and CV) }\end{array}$ & $\begin{array}{l}\text { Rhizosolenia alata }\left(100 \mu \mathrm{g} \mathrm{Cl}^{-1}\right. \\
\mathrm{C}: \mathrm{N}=5)\end{array}$ & & & $15 \pm 4$ & $\begin{array}{l}\text { Paffenhöfer \& Knowles } \\
\text { (1979) }\end{array}$ \\
\hline Pontella meadii & Natural food & $\begin{array}{c}12 \\
\text { (percentage }\end{array}$ & $\begin{array}{l}2-3 \\
\text { of } D W)\end{array}$ & 4.8 & Turner (1979) \\
\hline $\begin{array}{l}\text { Small copepods } \\
\text { Large copepods }\end{array}$ & Natural food & $\begin{array}{l}271 \\
324 \\
\text { lug per mg }\end{array}$ & $\begin{array}{r}50 \\
58 \\
\text { DW) }\end{array}$ & $\begin{array}{l}5.4 \\
5.6\end{array}$ & Small et al. (1983) \\
\hline $\begin{array}{l}\text { Temora stylifera } \\
\text { (adults) }\end{array}$ & $\begin{array}{l}\text { Hymenomonas elongata } \\
(\mathrm{C}: \mathrm{N}=10)\end{array}$ & $\begin{array}{l}154 \\
\text { lng per pel }\end{array}$ & et) 18 & 8.5 & Abou Debs (1984) \\
\hline $\begin{array}{l}\text { Calanus pacificus } \\
\text { (females and } \mathrm{CV} \text { ) }\end{array}$ & $\begin{array}{l}\text { Thalassiosira weissflogii } \\
(\mathrm{C}: \mathrm{N}=6)\end{array}$ & & & 7.5 & Downs \& Lorenzen (1985) \\
\hline $\begin{array}{l}\text { Acartia tonsa and } \\
\text { Temora spp. }\end{array}$ & $\begin{array}{c}\text { Thalassiosira sp. }(\mathrm{C}: \mathrm{N}=9-13) \\
\text { Isochrysis galbana }(\mathrm{C}: \mathrm{N}=8-14) \\
\text { general equation }\end{array}$ & $\mathrm{N}$ faeces $=$ & $-0.64+1$ & $\begin{array}{l}10-16 \\
8-25 \\
C: N \text { food }\end{array}$ & $\begin{array}{l}\text { Checkley \& Enzeroth } \\
\text { (1985) }\end{array}$ \\
\hline $\begin{array}{l}\text { Pseudocalanus spp. } \\
\text { and Temora longicornis }\end{array}$ & $\begin{array}{l}\text { Thalassiosira weissflogii }(200- \\
\left.20000 \text { cels }^{-1} ; C: N=5.5\right)\end{array}$ & $\begin{array}{l}250 \\
\text { lug per mg }\end{array}$ & $\begin{array}{l}30 \\
\text { DW) }\end{array}$ & $7-9$ & Present study \\
\hline
\end{tabular}


organic material) might affect the nutritional value of faecal pellets.

A summary of the carbon and nitrogen content of copepod faecal pellets reported in the literature and in the present study is presented in Table 3. These data reveal the scarcity of information on the food conditions under which the faeces were produced reflecting the lack of a basis for the use of single values to convert the faecal flux to carbon and nitrogen fluxes. The present results support the view that food concentration does not change the composition of faecal pellets produced by copepod assemblages with similar nutritional response to those analyzed here. However, the differences among the reported values are striking and can most likely be attributed to differences in food quality in terms of carbon and nitrogen. The effect of these differences in the estimation of carbon and nitrogen fluxes from faecal fluxes demands further investigation.

Checkley \& Enzeroth (1985) postulated a linear relation between the $\mathrm{C}: \mathrm{N}$ ratio of faecal pellets produced by copepods fed phytoplankton with different $\mathrm{C}: \mathrm{N}$ values (Table 3), based on tropical and subtropical copepods. They suggested that this relation would not to be applicable to copepods in colder environments, particularly copepods with lipid reserves. The present results extend the use of their postulated relation to small copepods, including Pseudocalanus, Temora, and Acartia species, in colder areas. The $\mathrm{C}: \mathrm{N}$ ratio of particles in suspension which constitute the potential food supply of copepods range from 2 to 35 in the natural conditions (Poulet 1983). Recent observations have shown that on a scale of days the $\mathrm{C}: \mathrm{N}$ ratio of the food supply varies from 5 to 7 in Bedford Basin (Mayzaud \& Conover 1984). Therefore, it is likely that the faeces produced by surface copepod assemblages have a fluctuating $\mathrm{C}: \mathrm{N}$ ratio over both short and long temporal scales, which might result in high variability in the nutritional value of faecal pellets. However, the extent to which these variations are reflected in the specific carbon and nitrogen content of faecal pellets, and in the absolute magnitude of carbon and nitrogen fluxes via faecal pellets, cannot be predicted from C: $\mathrm{N}$ ratios.

The potential consumption of zooplankton faecal pellets in the water column (Smetacek 1980, Poulet 1983), and/or the potential contribution of these pellets to the downward transport of organic and inorganic materials (Angel 1984, Fowler \& Knauer 1986), emphasizes the need for further investigation. Specifically, the study of the processes that regulate the organic content of zooplankton faecal pellets and the residence time of the faecal pellets in the water column should be a priority in understanding the trophic transfers and the vertical flux of carbon and nitrogen in the ocean.
Acknowledgements. I thank Dr. B. Hargrave, for essential encouragement provided; Drs. R. J. Conover, J. Grant and anonymous reviewers, for comments and criticisms; and Dr. C. M. Boyd and Dalhousie University, for logistic support.

\section{LITERATURE CITED}

Abou Debs, C. (1984). Carbon and nitrogen budget of the calanoid copepod Temora stylifera: effect of food concentration and composition of food. Mar. Ecol. Prog. Ser. 15: $213-223$

Angel, M. V. (1984). Detrital organic fluxes through pelagic ecosystems. In: Fasham, M. J. R. (ed.) Flows of energy and materials in marine ecosystems. Theory and practice. Plenum Press, New York, p. 475-516

Beklemishev, C. V. (1962). Superfluous feeding of marine herbivorous zooplankton. Rapp. P.-v. Réun. Cons. perm. int. Explor. Mer 153: 108-113

Bienfang, P. K. (1980). Herbivore diet affects fecal pellet settling. Can. J. Fish. Aquat. Sci. 37: 1352-1357

Bruland, K. W., Silver, M. W. (1981). Sinking rates of fecal pellets from gelatinous zooplankton (Salps, Pteropods, Doliolids). Mar. Biol. 63: 295-300

Checkley, D. M. (1980). The egg production of a marine planktonic copepod in relation to its food supply: laboratory studies. Limnol. Oceanogr. 25: 430-446

Checkley, D. M., Enzeroth, L. C. (1985). Elemental and isotopic fractionation of carbon and nitrogen by marine, planktonic copepods and implications to the marine nitrogen cycle. J. Plankton Res. 7: 553-568

Conover, R. J., Huntley, M. (1980). General rules of grazing in pelagic ecosystems. In: Falkowski, P. (ed.) Primary productivity in the sea. Plenum Press, New York, p. 461-485

Dagg, M. (1985). The effects of food limitation on diel migratory behaviour in marine zooplankton. Arch. Hydrobiol. Beih. Ergeb. Limnol. 21: 247-255

Downs, J. N., Lorenzen, C. J. (1985). Carbon:phaeopigment ratios of zooplankton faecal pellets as an index of herbivorous feeding. Limnol. Oceanogr. 30: 1024-1036

Fowler, S. W., Knauer, G. A. (1986). Role of large particles in the transport of elements and organic compounds through the oceanic water column. Prog. Oceanogr. 16: 147-194

Frost, B. W. (1985). Food limitation of the planktonic marine copepods Calanus pacificus and Pseudocalanus sp. in a temperature fjord. Arch. Hydrobiol. Beih. Ergeb. Limnol. 21: $1-13$

Gamble, J. C. (1978). Copepod grazing during a declining spring phytoplankton bloom in the northern North Sea. Mar. Biol. 49: 303-315

Gaudy, R. (1974). Feeding four species of pelagic copepods under experimental conditions. Mar. Biol. 25: 125-141

Gerber, R. P., Gerber, M. B. (1979). Ingestion of natural particulate organic matter and subsequent assimilation, respiration and growth by tropical lagoon zooplankton. Mar. Biol. 52: 33-43

Gowing, M. M., Silver, M. W. (1985). Minipellets: a new abundant size class of marine faecal pellets. J. mar. Res. 43: 395-418

Guillard, R. R. L. (1975). Culture of phytoplankton for feeding marine invertebrates. In: Smith, W. L., Chanley, M. H. (ed.) Culture of marine invertebrate animals. Plenum Press, New York, p. 29-60

Hofmann, E. E., Klinck, J. M., Paffenhöfer, G.-A. (1981). Concentrations and vertical fluxes of zooplankton fecal pellets on a continental shelf. Mar. Biol. 61: 327-335 
Honjo, S., Roman, M. R. (1978). Marine copepod fecal pellets: production, preservation, and sedimentation. J. mar. Res. 36: $45-57$

Jacobsen, T. R., Azam, F. (1984). Role of bacteria in copepod fecal pellet decomposition: colonization, growth rates and mineralization. Bull. mar. Sci. 35: 495-502

Johannes, R. E., Satomi, M. (1966). Composition and nutritive value of fecal pellets of a marine crustacean. Limnol. Oceanogr. 11: 191-197

Kiørboe, T., Møhlenberg, F., Nicolajsen, H. (1982). Ingestion rate and gut clearance in the planktonic copepod Centropages hamatus in relation to food concentration and temperature. Ophelia 21: 181-194

Knauer, G. A., Martin, J. H., Bruland, K. W. (1979). Fluxes of particulate carbon, nitrogen and phosphorus in the upper water column of the northeast Pacific. Deep Sea Res. 26: 97-108

Koeller, P. A., Barwell-Clarke, J. E., Whitney, F., Takahashi, M. (1979). Winter condition of marine plankton populations in Saanich Inlet, B. C., Canada. III. Meso-zooplankton. J. exp. mar. Biol. Ecol. 37: 161-174

Kraneis, W., Martens, P. (1975). Ecological studies on the plankton in Kiel Bight II. Zooplankton. Merentutkimuslait. Julk./Havsforskningsinst. Skr. 239: 187-194

Landry, M. R., Hassett, R. P., Fagerness, V., Downs, J., Lorenzen, C. J. (1984). Effect of food acclimation on assimilation efficiency of Calanus pacificus. Limnol. Oceanogr. 29. 361-364

Madin, L. P. (1982). Production, composition and sedimentation of fecal pellets in oceanic waters. Mar. Biol. 67: 39-45

Marshall, S. M., Orr, A. P. (1955). The biology of a marine copepod, Calanus finmarchicus (Gunnerus). Oliver and Boyd, Edingburgh

Mayzaud, P., Conover, R. J. (1984). Distribution of digestive enzymes in zooplankton during the spring bloom in a Nova Scotia inlet. Can. J. Fish. Aquat. Sci. 41: 245-252

Mayzaud, P., Mayzaud, O. (1985). The influence of food limitation on the nutritional adaptation of marine zooplankton. Arch. Hydrobiol. Beih. Ergeb. Limnol. 21: 223-233

Mayzaud, P., Poulet, S. A. (1978). The importance of the time factor in the response of zooplankton to varying concentrations of naturally occurring particulate matter. Limnol. Oceanogr. 23: 1144-1154

McClatchie, S., Lewis, M. R. (1986). Limitations of grazing rate equations: the case for time-series measurements. Mar. Biol. 92: 135-140

Morales, C. (1986). Copepod faecal pellet composition: effect of food concentration, acclimation and ingestion rates. M. Sc. thesis, Dalhousie University, Halifax

O'Connors, H. B., Biggs, D. C., Ninivaggi, D. V. (1980). Particle-size-dependent maximum grazing rates for Temora longicornis fed natural particle assemblages. Mar. Biol. 56: $65-70$

Ohman, M. (1985). Resource-satiated population growth of the copepod Pseudocalanus sp. Arch. Hydrobiol. Beih. Ergeb. Limnol. 21: 15-32

Paffenhöfer, G.-A., Knowles, S. C. (1979). Ecological implications of fecal pellet size, production and consumption by copepods. J. mar. Res. 37: 35-49

Poulet, S. A. (1974). Seasonal grazing of Pseudocalanus minutus on particles. Mar. Biol. 25: 109-123

Poulet, S. A. (1976). Feeding of Pseudocalanus minutus on living and non-living particles. Mar. Biol. 34: 117-124

Poulet, S. A. (1978). Comparison between five coexisting species of marine copepods feeding on naturally occurring particulate matter. Limnol. Oceanogr. 23: 1126-1143

Poulet, S. A. (1983). Factors controlling utilization of nonalgal diets by particle grazing copepods. A review. Oceanologica Acta 6: 221-234

Roman, M. R., Rublee, P. A. (1980). Containment effects in copepod grazing experiments: a plea to end the black box approach. Limnol. Oceanogr. 25: 982-990

Small, L. F., Fowler, S. W., Moore, S. A., LaRosa, J. (1983). Dissolved and fecal pellet carbon and nitrogen release by zooplankton in tropical waters. Deep Sea Res. 30 : $1199-1220$

Smetacek, V. S. (1980). Zooplankton standing stock, copepod faecal pellets and particulate detritus in Kiel Bight. Estuar. coast. Shelf Sci. 11: 239-251

Stearns, D. E. (1986). Copepod grazing behavior in simulated natural light and its relation to nocturnal feeding. Mar. Ecol. Prog. Ser. 30: 65-76

Tanoue, E., Handa, N., Skugawa, H. (1982). Difference of the chemical composition of organic matter between fecal pellet of Euphausia superba and its food, Dunaliella tertiolecta. Trans. Tokyo Univ. Fish. 5: 189-196

Turner, J. T. (1977). Sinking rates of fecal pellets from the marine copepod Pontella meadii. Mar. Biol. 40: 249-259

Tumer, J. T. (1979). Microbial attachment to copepod fecal pellets and its possible ecological significance. Trans. Am. Microsc. Soc. 98: 131-135

Urrere, M. A., Knauer, G. A. (1981). Zooplankton faecal pellet fluxes and vertical transport of particulate organic materials in the pelagic environment. J. Plankton Res. 3: $369-387$

This article was presented by Dr R. J. Conover; it was accepted for printing on December 17, 1986 